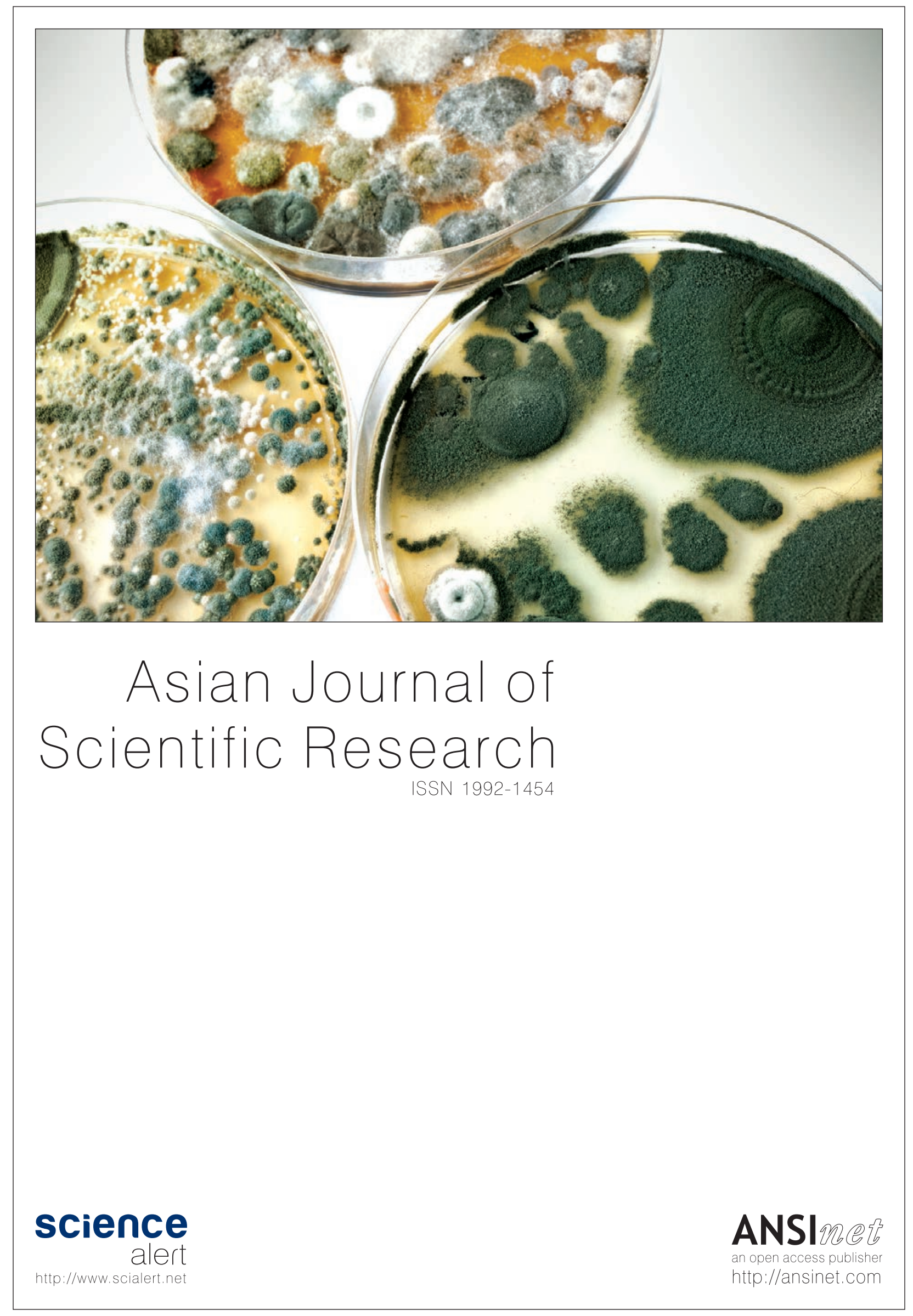




\title{
Research Article \\ Employee Engagement as a Mediator Between Transformational Leadership and Employee Performance
}

\author{
${ }^{1}$ Ong Choon Hee, ${ }^{1}$ Ruzilla Ibrahim, ${ }^{2}$ Tan Owee Kowang and ${ }^{2}$ Goh Chin Fei \\ ${ }^{1}$ Azman Hashim International Business School, Universiti Teknologi Malaysia, 81310 Johor Bahru, Johor, Malaysia \\ ${ }^{2}$ Faculty of Management, Universiti Teknologi Malaysia, 81310 Johor Bahru, Johor, Malaysia
}

\section{Abstract}

Background and Objective: Transformational leadership and employee engagement have been much studied in the private industry but very little has been done in the public sector. This study was conducted in the Malaysian public sector to discover its impact on employee performance. This study aimed to develop a conceptual model and to examine employee engagement as a mediator between transformational leadership and employee performance in the public sector of a developing country. Materials and Methods: The data were collected through a survey of 200 employees in a public sector organization in Malaysia. Self-administered questionnaire was used for data collection. The sample size was determined according to the sample size at the level of confidence of $95 \%$ and significant level of 0.05 . Stratified random sampling technique was used to achieve the objectives of this research. The survey instruments used in this study consisted of 34 items relating to 3 constructs namely employee engagement (EE, 11 items), employee performance (EP, 13 items) and transformational leadership (TR, 10 items). Results: Results of the partial least square structural equation modeling (PLS-SEM) revealed that transformational leadership was positively related to employee performance. In addition, the analysis also showed that employee engagement fully mediates the relationship between transformational leadership and employee performance. Conclusion: This study suggested that policy makers should introduce organizational interventions that encapsulate both transformational leadership and employee engagement to enhance employee performance in the public sector.

Key words: Employee engagement, transformational leadership, employee performance, public sector, sustainability

Received: February 21, $2018 \quad$ Accepted: May 04, $2018 \quad$ Published: June 15, 2018

Citation: Ong Choon Hee, Ruzilla Ibrahim, Tan Owee Kowang and Goh Chin Fei., 2018. Employee engagement as a mediator between transformational leadership and employee performance. Asian J. Sci. Res., 11: 441-448.

Corresponding Author: Ong Choon Hee, Azman Hashim International Business School, Universiti Teknologi Malaysia, 81310 Johor Bahru, Johor, Malaysia Tel: +60755610112

Copyright: @ 2018 Ong Choon Hee et al. This is an open access article distributed under the terms of the creative commons attribution License, which permits unrestricted use, distribution and reproduction in any medium, provided the original author and source are credited.

Competing Interest: The authors have declared that no competing interest exists.

Data Availability: All relevant data are within the paper and its supporting information files. 


\section{INTRODUCTION}

The emergence of transformational and fast-paced high thinking leadership has caused organizations to look for methods to strive effectively to sustain in the competitive environment ${ }^{1}$. Obsolete business models, outdated leadership practices and old-fashioned thinking will not heighten growth in the ever changing highly demanding world. Thus, the adaptation of the most suitable leadership style and thoughtful approach is needed as to move the whole team to the right direction of the organization goals ${ }^{1}$. To achieve the organization's mission and vision, leaders play an important role in exhibiting appropriate leadership style and behaviors while dealing with subordinates or employees ${ }^{2}$. Leadership style critically determines the actions of the employees moving toward the same direction together with the leaders in achieving the organization goals².

Every organization has its own mission and vision as well as their goal path towards success and sustainability in doing business. The reason why the shift of attention focus more on leadership style is that it is acknowledged as the root construct in helping leaders and organization to clarify issues and assisting the management in overcoming problems ${ }^{1,2}$. According to Leavy ${ }^{1}$, leaders with high performance characters are able to deliver better business performance and such leadership style is also associated with much higher level of employee engagement. Through adequate commitment to self-development, good leadership characters and behaviors can be reinforced and bad ones eliminated. An organization often emphasizes on the importance of its mission, technology, strategies, training and development in attaining sustainability in the industry. However, more often than not, the organization could miss out a very important factor which is the people in the organization itself as the key factor in achieving success. The term 'people' is referred to the significant roles of the leaders in influencing employee engagement where by eventually will lead to better employee performance.

The most important societal values according to Carter, and Greer $^{2}$ in Eastern and Western societies are justice, fairness, opportunity, engagement and freedom in the workplace. Leadership style focuses on these topics has become a huge concern in both academic and the real world. It is acknowledged as the basic variables that may help leaders to identify the suitable approach in formulating solution for the organizational problems. Employee engagement and employee performance are two of the core elements in an efficient organization. Since there has been very little attention paid to the public sector employee performance and its predictors are still unclear, the objective of this study intends to examine the relationship between transformational leadership and employee performance with employee engagement as a mediator in this context. Samples of this research would involve both employees and leaders for their perception of transformational leadership, employee engagement and employee performance in the public sector organization in Malaysia.

Employee performance is referred to the outcome achieved and accomplished at work and is being evaluated to ascertain levels of activities completed according to the aimed results. According to Cardy ${ }^{3}$, in the context of performance management, performance evaluation is not only the most important element but also depends on the policies, designs and features of an organization. Employee performance is proven to have substantial positive effects on organizational performance ${ }^{4}$. Employee performance can be defined as how well the employees perform in their job and tasks. Performance indices are instruments to evaluate goal achievement. Each organization has their own goals, employees were hired to ensure the organization's goals are achieved with controllable activities and effective operation. Mostly, employee performance was affected by employees' behavior instead of the actions taken to achieve the goal. This is due to the fact that most results of the employee performance were affected by environment factors which are uncontrollable and beyond the reach of human being. Organizations can be divided into two types, namely profit organization and non-profit organization. Chi et al. ${ }^{5}$ indicated that employee performance for profit organization can be measured by revenue, production and profit making of the organization, whereas for non-profit organization, mission accomplishment is the performance index. They did not evaluate performance by profits because they do not have guidelines whether the decision made is correct and the resource used is appropriate.

According to Borman and Motowidlo, task performance can be defined as contribution to the organization directly or indirectly. Direct contribution is an activity which employees give support to the organization by implementing a part of its technological processes. While indirect contribution means it is contributed by providing necessary and needed materials or services. In addition, Borman and Motowidlo ${ }^{6}$ also argued that contextual performance is different from task performance. Contextual performance does not have direct job performance that can be measured by revenues, production output and profit making but in ways like employee's support in shaping organizational, social and psychological context which serves as catalyst for task activities processes. This brings huge 
impact in achieving overall organizational performance. Contextual activities may include volunteering to support co-workers to complete the job and task activities that are out of the job scope. Contextual activities are important because employees contribute to the organizational effectiveness. Organizational citizenship behavior is one of the contextual performances. Therefore, employee performance is a combination of task and contextual performance. It is not only a personal achievement but it also contributes to the organizations achievement at large.

Transformational leadership was created first by Burns ${ }^{7}$ who developed his theory about transformational leadership based on political leaders in his research. The Burns ${ }^{7}$ emphasized that the vast difference between transformational leadership and transactional "occurs when one or more persons engage with others in such a way that leaders and followers raise one another to higher level of motivation and morality". The findings by Burns ${ }^{7}$ described that political leaders who successfully appealed to higher principles and moral values, able to influence the followers with the concept of transformational leadership. In transformational leadership, the Burns ${ }^{7}$ mentioned that there is an in depth connectivity in terms of performance, commitment and moral values of both followers and leaders. According to the study of a Keskes ${ }^{8}$, it was revealed that transformational leadership is a process of seeking aggregate objectives through mutual tapping of leaders' and followers' intention towards the accomplishment of change. On the other hand, Lian and Tui ${ }^{9}$ discussed that transformational leadership occurred when employees adopted the leader's ultimate values by making changes in beliefs, perspectives and objectives. Leaders' responsibilities are to transform the employees' perceptions according to their needs and redirect them to a higher level. Employees believed that the organization was extraordinary and thus they were highly satisfied and motivated to perform additional roles $^{10}$. Generally, employees were inspired and motived by their leaders.

Transformational leadership is not only focusing on tasks and jobs in the organization but also motivate followers to achieve higher level of performance ${ }^{7}$. Motivating employees to get into collective purpose of teamwork instead of individual personal gain is a critical element inspired by transformational leaders to accomplish goals and even surpass the mission of higher performance ${ }^{11}$. A research conducted by Ling et al. ${ }^{12}$ on 121 CEOs in 121 small and medium enterprises (SMEs) had examined the impact of CEO's transformational leadership on employee performance in the company. Other variables of the study include firm's size, status of founder of the company and CEO tenure as a moderator affecting the relationship between the transformational leadership and employee performance. The findings of the study found that there is a significant positive relationship between CEOs practicing transformational leadership and employee performance $^{12}$. Thus, based on the above discussion, the following hypothesis is proposed:

H1: Transformational leadership has a positive relationship with employee performance.

Employee engagement is defined as the stages of commitment and willingness to sacrifice beyond expectation to bring the best of their capabilities towards their organization and values. An engaged employee is alert on the mission and goals of his organization and optimistically motivates colleagues around him to progress according to the objectives and goals. The optimistic value of the employee with his work place and its value system is called positive emotional connection towards his work. Kahn ${ }^{13}$ conceptualized engagement at work as "harnessing of organizational members' selves to their work roles". The engagement refers to "people employ and express themselves physically, cognitively and emotionally during role performances". The concept has taken into consideration various factors in defining an engaged employee including behavioral factors displayed by the employee who is positively productive. The research identifies major variables through a detailed literature which explained employee engagement and the impact on employee performance in an organization. A study of Sarti ${ }^{14}$ examined the relationship between work engagement and leadership styles in human service organizations. There were two types of leadership being explored in the study namely participative and instrumental leadership. Employees who work in nine human service organizations in Italy were chosen to be the respondents of the study. The findings show that dimensions of employee engagement were related to leadership styles. It was found that participative leadership of the supervisors is particularly significant in predicting vigor and dedication among employees whereby instrumental leadership is positively related to vigor and absorption. Additionally, it was observed that actively involved employees in the organization represent high level of employee engagement which forms a key component in the achievement of the organizational objectives.

According to Macey et al. ${ }^{15}$, employee engagement can be a source of sustainable competitive advantage. Employee engagement is described as one of the key determinants in nurturing and escalating level of employee performance ${ }^{15}$. 
This study aims to examine the determinants of employee engagement and the strength of impact on employee performance. Highly engaged employees are found to have passion for their job and believe that they have deep connection to their organization. They yield positive energy, perception and attention into their job which lead to effective and efficient performance. Based on the study of 8,000 business units in 36 organization by Robbins and Judge ${ }^{16}$, it was found that highly engaged employees are able to produce optimum customer satisfaction, more productive, experienced lower turnover and lower accidents than business units of disengaged employees. Therefore, employee engagement is essential for an organization in order to obtain higher productivity and higher performance. In today's competitive world of business, employee engagement can be acquired optimistically in conjunction with a strong leadership style to produce higher employee performance. Hence, on the basis of the above discussion, the following hypothesis is proposed:

$\mathrm{H} 2$ : Employee engagement mediates the relationship between transformational leadership and employee performance

Based on the literature review and empirical studies, a model was proposed and tested in which transformational leadership predicts employee performance and mediated by employee engagement (Fig. 1).

\section{MATERIALS AND METHODS}

The sample being considered in this study consisted of staffs in one public sector organization in Malaysia. The population is the entire group of individuals that the whole information is all about. Since the population of the organization is amounted to 397 staffs overall, the number of respondents of the required sample size would be 172. The sample size was determined according to the sample size at the level of confidence of $95 \%$ and significant level of 0.05 as stated by Krejcie and Morgan ${ }^{17}$. Stratified random sampling technique was used to achieve the objectives of this research. The survey instruments used in this study consisted of
34 items relating to 3 constructs namely employee engagement ( $E E, 11$ items), employee performance (EP, 13 items) and transformational leadership (TR, 10 items). Items for employee engagement and employee performance were adapted from Thomas ${ }^{18}$ and Pearce and Porter ${ }^{19}$, respectively. Measures for transformational leadership were adapted from multifactor leadership questionnaires (MLQ) developed by Avolio et al. ${ }^{20}$. Likert scale was used in this study, ranging from 1 (strongly disagree) to 5 (strongly agree). Nominal scales were used to obtain information on respondents' personal backgrounds. This study used partial least square structural equation modeling technique (PLS-SEM) to examine the correlational relationship among the study variables. Smart PLS v. 3 was used to test the conceptual model in the present study. Bootstrapping technique of estimating indirect effects by Preacher and Hayes ${ }^{21}$ was employed to test the mediating effects in the model.

\section{RESULTS}

Demographic profile: A total of 250 self-administered questionnaires were distributed to the employees of the organization and only 215 were returned to the researcher. Out of 215 questionnaires, only 200 were useable and thus yield a response rate of $80 \%$ and exceeded the minimum required sample size of 172 . Refer to Table 1, most of the respondents were females (65\%) compared to males (35\%). Majority (35\%) of the respondents were categorized 1-5 years of service and most of them were in the grade position of $21-32$ (47\%). $85 \%$ of the respondents were permanent staffs.

Measurement model: To assess the PLS-SEM measurement model, a reflective model was used to evaluate the construct and its underlying items ${ }^{22}$. The reliability of the scale was tested by assessing indicator reliability, composite

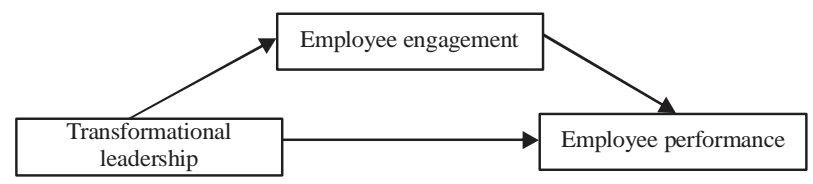

Fig. 1: Conceptual model

Table 1: Profile of the respondents

\begin{tabular}{lll}
\hline Gender & Length of service & Grades of position \\
\hline Male $=70(35 \%)$ & $1-5$ years $=70(35 \%)$ & $<$ J $21=18(9 \%)$ \\
Female $=130(65 \%)$ & $6-10$ years $=38(19 \%)$ & G21-32 $=94(47 \%)$ \\
& $11-19$ years $=40(20 \%)$ & G $41-44=86(43 \%)$ \\
& $>20$ years $=52(26 \%)$ & G $48-52=2(1 \%)$ \\
\hline
\end{tabular}




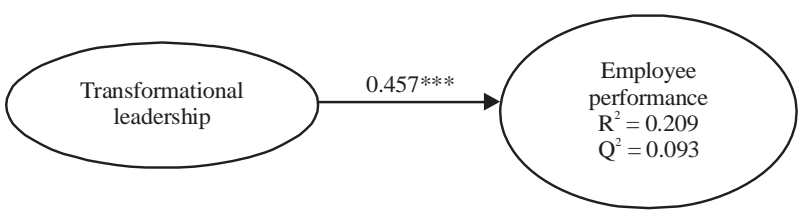

Fig. 2: Structural model (without mediator). ${ }^{*}$ Significant at $p<0.1,{ }^{* *}$ Significant at $p<0.05,{ }^{* * *}$ Significant at $p<0.01$

\begin{tabular}{|c|c|c|c|c|}
\hline $\begin{array}{l}\text { Constructs/ } \\
\text { indicators }\end{array}$ & Loading & $\begin{array}{c}\text { Cronbach's } \\
\text { alpha }\end{array}$ & $C R$ & AVE \\
\hline \multicolumn{5}{|c|}{ Employee engagement (EE) } \\
\hline EE1 & 0.667 & 0.905 & 0.921 & 0.518 \\
\hline EE2 & 0.737 & & & \\
\hline EE3 & 0.787 & & & \\
\hline EE4 & 0.737 & & & \\
\hline EE5 & 0.782 & & & \\
\hline EE6 & 0.658 & & & \\
\hline EE7 & 0.762 & & & \\
\hline EE8 & 0.796 & & & \\
\hline EE9 & 0.777 & & & \\
\hline EE10 & 0.512 & & & \\
\hline EE11 & 0.646 & & & \\
\hline \multicolumn{5}{|c|}{ Employee performance (EP) } \\
\hline EP1 & 0.597 & 0.921 & 0.933 & 0.540 \\
\hline EP2 & 0.789 & & & \\
\hline EP3 & 0.796 & & & \\
\hline EP4 & 0.775 & & & \\
\hline EP5 & 0.654 & & & \\
\hline EP6 & 0.813 & & & \\
\hline EP7 & 0.812 & & & \\
\hline EP8 & 0.828 & & & \\
\hline EP9 & 0.691 & & & \\
\hline EP10 & 0.748 & & & \\
\hline EP11 & 0.591 & & & \\
\hline EP12 & 0.669 & & & \\
\hline \multicolumn{5}{|c|}{ Transformational leadership (TR) } \\
\hline TR1 & 0.743 & 0.923 & 0.936 & 0.595 \\
\hline TR2 & 0.771 & & & \\
\hline TR3 & 0.784 & & & \\
\hline TR4 & 0.758 & & & \\
\hline TR5 & 0.812 & & & \\
\hline TR6 & 0.688 & & & \\
\hline TR7 & 0.666 & & & \\
\hline TR8 & 0.836 & & & \\
\hline TR9 & 0.851 & & & \\
\hline TR10 & 0.786 & & & \\
\hline
\end{tabular}

CR: Composite reliability, AVE: Average variance extracted

\begin{tabular}{lccc} 
Table 3: Discriminant validity & & & \\
\hline & $\begin{array}{c}\text { Employee } \\
\text { Engagement }\end{array}$ & $\begin{array}{c}\text { Employee } \\
\text { performance }\end{array}$ & $\begin{array}{c}\text { Transformational } \\
\text { leadership }\end{array}$ \\
\hline Employee engagement & 0.719 & & \\
Employee performance & 0.707 & 0.735 & \\
Transformational leadership & 0.572 & 0.435 & 0.771 \\
\hline
\end{tabular}

reliability (CR) and Cronbach's Alpha. Next, convergent validity was assessed based on the average variance extracted (AVE) values $^{23}$. Finally, discriminant validity was determined by comparing the squared root of AVE of the constructs with correlations between other constructs using criterion ${ }^{24}$. For this study, there was one exogenous construct, namely transformational leadership (TR) and two endogenous constructs, specifically employee engagement (EE) and employee performance (EP).

Based on the results of the measurement model in Table 2, outer loadings of the constructs were exceeded the cut-off value of 0.50 . Outer loadings below 0.50 were deleted from the measurement model as proposed by Barclay et $a / .{ }^{25}$. As presented in Table 2, 33 items with outer loadings ranging from 0.512-0.851 were retained. The internal consistency reliability of the constructs were measured by using composite reliability (CR) and Cronbach's Alpha. All the values of composite reliability and Cronbach's Alpha surpassed the minimum value of 0.70 as recommended by $\mathrm{Chin}^{26}$. Thus, the three constructs met the criterion of the internal consistency reliability. Next, it is evaluated the convergent validity and found that the average variance extracted (AVE) of all the constructs were above the minimum value of 0.50 as recommended by Hair et al.23. Hence, it indicates that more than half of the construct variances were explained by the relevant indicators.

Finally, discriminant validity was tested by using a Fornell and Larcker ${ }^{27}$ criterion. It was found in Table 3 that the square roots of AVE for each construct (diagonal values) were greater than the correlations among other constructs in rows and columns. Therefore, it is suggested that adequate discriminant validity was observed and each construct in the model was unique and individually measured.

Structural model: In order to test the hypothetical relationships and mediating effect of the conceptual model, author used methods suggested by Hair et al. ${ }^{28}$ and bootstrapping techniques developed by Preacher and Hayes ${ }^{21}$ to estimate the indirect effect of the mediation model. First, it is tested the relationship whether transformational leadership is positively related to employee performance. The analysis results showed that transformational leadership has a positive significant relationship with employee performance $(\beta=0.457$, $p=0.000$ ). Next, it was performed blind folding procedure to ascertain the predictive relevance of the model where Q2 value (0.093) was larger than zero and indicates that the model has predictive ability ${ }^{24}$. The structural model without a mediator (Fig. 2) was able to explain $20.9 \%$ of the total variance in employee performance. As such, hypothesis 1 was supported. 


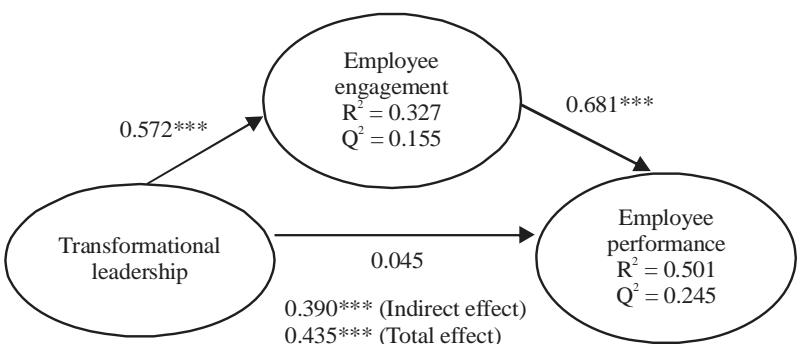

Fig. 3: Structural model (with mediator). ${ }^{*}$ Significant at $p<0.1$, ${ }^{* *}$ Significant at $p<0.05,{ }^{* * *}$ Significant at $p<0.01$

Next, assessed the structural model with the presence of a mediator namely employee engagement. Figure 3 showed that the coefficient of determination $\left(R^{2}\right)$ value has been increased to 0.501 which suggested that employee performance can be explained $50.1 \%$ of the total variance by transformational leadership and employee engagement. Furthermore, the $\mathrm{Q}^{2}$ value for employee performance was 0.245 which is well above zero, hence, indicating predictive relevance of the mode ${ }^{29}$. Path coefficient $(\beta=0.390, p=0.000)$ were found to be significant for indirect effect between transformational leadership and employee performance via employee engagement.

However, the direct effect ( $\beta=0.045, p=0.495)$ between transformational leadership and employee performance was not significant (Fig. 3). As such, it can be concluded that employee engagement mediates the relationship between transformational leadership and employee performance. To test the strength of the mediating effect, VAF (variance accounted for) was used by dividing indirect effect with total effect. The VAF value was found to be $89.7 \%$ with indirect effect of $0.390, p<0.01$ and total effect of $0.435, p<0.01$ thus suggesting that employee engagement is a full mediator. Based on the explanation above, hypothesis 2 was supported.

\section{DISCUSSION}

The first hypothesis of this research sought to identify the relationship between transformational leadership on employee performance. Based on the results of analysis, it was found that the direct effect between transformational leadership and employee performance $(\beta=0.457, p=0.000$ ) was significant. Hence, is proven that transformational leadership has a positive and significant relationship with employee performance. The findings from this study are consistent with a study by Camps and Rodriguez ${ }^{30}$ that transformational leadership enhanced self-perceived employability, commitment and performance. The questionnaires in this study measured the level of agreement among respondents in displaying transformational leadership in the organization. Majority of the respondents agreed upon transformational traits of leadership has been displayed by leaders in the organization. In addition, this study has established causal relationship between perceived transformational leadership and employee performance. It offers a thorough understanding of the importance of transformational leadership in driving employee performance in the public sector organization. The traits of transformational leadership create positive environment, increase motivation and boost up morale of employees, hence leading to higher performance throughout the journey towards target accomplishment. Leaders are groomed to be the right role model for employees whom they will try to inspire and getting the employees to be engage in work, able to challenge the employees to own sense of belonging in the organization and align employees towards the same organizational objectives ${ }^{31}$. The analytical findings in this study support the notion that transformational leaders are able to assign tasks to the employees in accordance with their capabilities. This in return will allow employees to experience success and gain more self-confidence in achieving excellent performance ${ }^{31}$.

The relationship between transformational leadership and employee performance were found to be significant according to the analysis ( $\beta=0.457, p=0.000$ ). However, with the inclusion of employee engagement as the mediator, the direct relationship between transformational leadership with employee performance was no longer significant $(\beta=0.045$, $p=0.495$ ). The indirect effect of transformational leadership and employee performance via employee engagement was $(\beta=0.390, p=0.000$ ) thereby accepting $\mathrm{H} 2$. The VAF value at $89.7 \%$ indicates employee engagement was a full mediator in the relationship between transformational leadership and employee performance. The findings of this study are consistent with Tims et al. ${ }^{32}$ study where they found that employees' positivity were boosted by having transformational leaders and consequently increasing their work engagement. In this sense, leaders in this public sector organization while applying transformational traits in their leadership, must increase employee engagement in all employees in order to increase employee performance. The level of employee engagement in the organization will eventually affects the employee performance. The involvement of employee engagement in boosting up performance is supported specifically on how engaged employees enthusiastically involved in creating and cultivating new knowledge and skill, responding to opportunities and going the extra mile ${ }^{33}$. The feeling of sense of belonging of the respondents in the current organization is 
high as the level of employee engagement measured in the analysis. However, the analysis indicates that employee engagement cannot be detached when investigating transformational leadership and employee performance phenomena in the organization ${ }^{34}$. From a managerial perspective, employee engagement can be used as an effective mechanism to increase employee performance ${ }^{35}$. Increasing transformational leadership practices may not be sufficient as employee engagement mediates the positive effect of transformational leadership on employee performance ${ }^{36}$. In short, this outcome of the analysis proved that significant increase in higher employee performance could be seen if leaders with transformational traits encourage more employee engagement in the organization.

\section{CONCLUSION}

The findings of this study imply that transformational leadership is positively related to employee engagement, which in turn predicts employee performance. Additionally, the present study also demonstrates that employee engagement is indispensable in predicting employee performance. Overall, the major outcome of the results indicates that employee engagement is a full mediator between transformational leadership and employee performance.

\section{SIGNIFICANCE STATEMENT}

This study introduced employee engagement as a mediator between transformational leadership and employee performance which has not been tested empirically specifically in the public organizations in Malaysia. The results reveal that employee engagement is a full mediator in the relationship between transformational leadership and employee performance. The findings of this study further confirm that employee engagement cannot be detached when investigating transformational leadership and employee performance in the public sector and policy makers should use it as an effective mechanism to enhance employee performance.

\section{ACKNOWLEDGMENT}

The authors would like to thank the Malaysian Ministry of Higher Education and Universiti Teknologi Malaysia (Vot: 14J81) for providing financial support to publish this paper.

\section{REFERENCES}

1. Leavy, B., 2016. Effective leadership today-character not just competence. Strategy Leadersh., 44: 20-29.

2. Carter, S.M. and C.R. Greer, 2013. Strategic leadership:Values, styles and organizational performance. J. Leadersh. Organiz. Stud., 20: 375-393.

3. Cardy, R.L., 2004. Performance Management:Concepts, Skills and Exercises. M. E. Sharpe, Armonk, New York.

4. Collis, D.J. and C.A. Montgomery, 1995. Competing on resources: Strategy in the 1990s. Harvard Bus. Rev., 73: 118-128.

5. Chi, H.K., H.R. Yeh and C.H. Yu, 2008. The effects of transformation leadership, organizational culture, job satisfaction on the organizational performance in the non-profit organizations. J. Global Bus. Manage., 4: 129-137.

6. Borman, W.C. and S.J. Motowidlo, 1997. Task performance and contextual performance: The meaning for personnel selection research. Hum. Perform., 10: 99-109.

7. Burns, J.M., 1978. Leadership. Harper and Row, New York, USA., ISBN: 9780060105884.

8. Keskes, I., 2014. Relationship between leadership styles and dimensions of employee organizational commitment: A critical review and discussion of future directions. Intangible Capital, 10: 26-51.

9. Lian, L.K. and L.G. Tui, 2012. Leadership styles and organizational citizenship behavior: The mediating effect of subordinate's competence and downward influence tactics. J. Applied Bus. Econ., 13: 59-96.

10. Sechudi, O.O., 2014. The relationship between transformational leadership and organisational citizenship behaviour. Industrial and Organisational Psychology, University of South Africa, pp: 41-72.

11. Bucic, T., L. Robinson and P. Ramburuth, 2010. Effects of leadership style on team learning. J. Workplace Learn., 22: 228-248.

12. Ling, Y., Z. Simsek, M.H. Lubatkin and J.F. Veiga, 2008. Transformational leadership's role in promoting corporate entrepreneurship: Examining the CEO-TMT interface. Acad. Manage. J., 51: 557-576.

13. Kahn, W.A., 1990. Psychological conditions of personal engagement and disengagement at work. Acad. Manage. J., 33: 692-724.

14. Sarti, D., 2014. Leadership styles to engage employees: Evidence from human service organizations in Italy. J. Workplace Learn., 26: 202-216.

15. Macey, W.H., B. Schneider, K.M. Barbera and S.A. Young, 2009. Employee Engagement: Tools for Analysis, Practice and Competitive Advantage. Wiley-Blackwell, Malden, MA.

16. Robbins, S.P. and T.A. Judge, 2015. Organizational Behavior. 16th Edn., Pearson Education Limited, USA. 
17. Krejcie, R.V.and D.W. Morgan, 1970. Determining sample size for research activities. Educ. Psychol. Meas., 30: 607-610.

18. Thomas, C.H., 2007. A new measurement scale for employee engagement: Scale development, pilot test and replication. Acad. Manage. Proc., 2007: 1-6.

19. Pearce, J.L. and L.W. Porter, 1986. Employee responses to formal performance appraisal feedback. J. Applied Psychol., 71: 211-218.

20. Avolio, B.J., B.M. Bass and D.I. Jung, 1999. Re-examining the components of transformational and transactional leadership using the multifactor leadership. J. Occup. Organiz. Psychol., 72: 441-462.

21. Preacher, K.J. and A.F. Hayes, 2008. Asymptotic and resampling strategies for assessing and comparing indirect effects in multiple mediator models. Behav. Res. Methods, 40: 879-891.

22. Henseler, J., C.M. Ringle and R.R. Sinkovics, 2009. The Use of Partial Least Squares Path Modeling in International Marketing. In: New Challenges to International Marketing (Advances in International Marketing, Volume 20), Cavusgil, T., R.R. Sinkovics and P.N. Ghauri (Eds.). Emerald Group Publishing Ltd., Bingley, UK., ISBN-13: 978-1848554689, pp: 277-319.

23. Hair, J.F., C.M. Ringle and M. Sarstedt, 2011. PLS-SEM: Indeed a silver bullet. J. Market. Theory Pract., 19: 139-152.

24. Fornell, C. and J. Cha, 1994. Partial Least Squares. In: Advanced Methods of Marketing Research, Bagozzi, R.P. (Ed.). Blackwell Publishing Co., Cambridge, pp: 52-78.

25. Barclay, D., C. Higgins and R. Thompson, 1995. The Partial Least Squares (PLS) approach to causal modeling: Personal computer adoption and use as an illustration. Technol. Stud., 2: 285-309.

26. Chin, W.W., 2010. How to Write Up and Report PLS Analyses. In: Handbook of Partial Least Squares: Concepts, Methods and Application, Vinzi, V.E., W.W. Chin, J. Henseler and H. Wang (Eds.). Springer, New York, USA., ISBN-13: 9783540328254 , pp: 655-690.
27. Fornell, C. and D.F. Larcker, 1981. Evaluating structural equation models with unobservable variables and measurement error. J. Market. Res., 18: 39-50.

28. Hair, Jr., J.F., M. Sarstedt, L. Hopkins and V.G. Kuppelwieser, 2014. Partial Least Squares Structural Equation Modeling (PLS-SEM): An emerging tool in business research. Eur. Bus. Rev., 26: 106-121.

29. Chin, W.W., 1998. The Partial Least Squares Approach to Structural Equation Modeling. In: Modern Methods for Business Research, Markoulides, G.A. (Ed.). Lawrence Erlbaum, Mahwah, New Jersey, USA., pp: 295-336.

30. Camps, J. and H. Rodriguez, 2011. Transformational leadership, learning and employability: Effects on performance among faculty members. Personnel Rev., 40: 423-442.

31. Ahmet, A., 2015. The role of leadership and organizational citizenship behaviour in efficient management. Afr. J. Bus. Manage., 9: 727-734.

32. Tims, M., A.B. Bakker and D. Xanthopoulou, 2011. Do transformational leaders enhance their follower's daily work engagement? Leadership Quart., 22: 121-131.

33. Lockwood, N.R., 2007. Leveraging employee engagement for competitive advantage: HR's strategic role. HR Magaz., 52: 1-11.

34. Baloch, Q.B., N. Ali and G. Zaman, 2014. Measuring employees commitment as outcome of transformational and transactional leadership styles: An empirical study. Abasyn J. Soc. Sci., 3: 208-214.

35. Markos, S. and M.S. Sridevi, 2010. Employee engagement: The key to improving performance. Int. J. Bus. Manage., 5: 89-96.

36. Dajani, M.A.Z., 2015. The impact of employee engagement on job performance and organisational commitment in the Egyptian banking sector. J. Bus. Manage. Sci., 3: $138-147$. 